\title{
Interpretasi Makna Haji Yang Melekat Pada Masyarakat Bugis
}

\author{
Nasruddin \\ IAIN Parepare \\ Email. nasruddinsoni@iainpare.ac.id
}

\begin{abstract}
Abstrak. Interpretasi haji sangatlah bermakna di kalangan masyarakat bugis. Haji diinterpretasikan ke dalam kehidupan sosial masyarakat dan cara berpakaian digunakan untuk merujuk kepada simbol kehajian. Perilaku berpakaian adalah interpretasi makna dari simbol haji yang melekat pada masyarakat bugis. Semua pakaian dari berbagai macam bentuknya adalah simbolik. Pakaian adalah salah satu cara melambangkan status sosial seseorang dalam masyarakatnya. Gelar haji bagi masyarakat bugis pada umumnya dianggap sebagai simbol yang berharga dalam status sosial.
\end{abstract}

Kata Kunci: Haji, Simbolik, Masyarakat, Bugis

Abstract. Interpretation of Hajj is very meaningful in the Bugis community. Hajj is interpreted into the social life of the society and the way of clothes is used to refer to the symbols of Hajj. Clothing behavior is the interpretation of the meaning of the hajj symbol attached to the Bugis society. All clothes of various shapes are symbolic. Clothing is one way to symbolize a person's social status in society. The title of hajj for the Bugis community is generally considered a valuable symbol of social status.

Keywords: Hajj, Simbolic, Society, Buginese

\section{PENDAHULUAN}

Salah satu kodrat yang dimiliki manusia yaitu sebagai makhluk sosial. Manusia dikatakan sebagai makhluk sosial karena tak satupun manusia yang mampu hidup sendiri tanpa bantuan orang lain atau bahkan bantuan makhluk hidup lainnya. Misalnya anjing yang dapat membantu manusia untuk menjaga rumahnya. Oleh sebab itu, manusia dalam kehidupan sehariharinya pasti melakukan interaksi dengan orang lain maupun makhluk hidup lainnya. Dalam interaksi tersebut, manusia memiliki sistem simbol dalam berkomunikasi, manusia menyusun simbol-simbol tersebut serta memberikan tanda sebagai bentuk identifikasi terhadap dirinya, maka tak heran jika manusia dikatakan sebagai makhluk yang bersimbolik.

Setiap manusia dalam berinteraksi tidak pernah lepas dari simbol-simbol yang dimilikinya mereka memberikan makna dari simbol-simbol tersebut (Blumer, 1966). Bagi mereka makna-makna itu merupakan hasil dari interaksi sosial dalam masyarakat manusia, makna-makna dimodifikasi dan ditangani melalui suatu proses penafsiran yang digunakan oleh setiap individu dalam keterlibatannya dengan tanda-tanda yang dihadapinya. Pernyataan dari Cassirer memaknai manusia sebagai makhluk simbolik (Sarwono, 2012). Manusia memiliki kekuatan yang bernama akal budi, dengan akal budi itu manusia menyusun simbol-simbol berupa mitos, bahasa, kesenian, agama, sejarah, dan ilmu pengetahuan. Simbol-simbol itulah manusia menguasai dunianya, baik alam fisiknya seperti sungai, gunung, udara dan lain-lain maupun alam sosialnya (masyarakat). Sebagai hasil, Blumer (1966) mengatakan bahwa pada dasarnya manusia dalam melakukan komunikasi dengan manusia lainnya selalu menyodorkan simbolsimbol yang ada pada dirinya, mereka seakanakan menyodorkan secara subjektif kepada lawan komunikasinya agar diberikan pemaknaan terhadap simbol-simbol yang mereka bawa (Poloma, 2007). Cassirer lebih ekstrim memaknai manusia sebagai makhluk simbolik, karena manusia memiliki kekuatan yang disebut dengan akal budi menurutnya, 
apapun yang dipandang manusia sebagai ide dalam pemikirannya seperti ide tentang alam, bahasa, kesenian, agama, sosial dan lain sebagainya maka manusia memberi ruang kepada dirinya untuk menyusun simbolsimbol tersebut (Sarwono, 2012). Oleh karena itu, manusia dalam hidup dan kehidupannya tidak pernah lepas dari simbol-simbol, setiap simbol itu ada maknanya tergantung dari individu atau kelompok mana yang memberikan pemaknaan dari simbol tersebut. Termasuk dalam praktek keagamaan, misalnya Ibadah haji adalah ibadah yang penuh dengan simbol yang memiliki makna tersendiri, didalam pelaksanaannya.

Oleh karena itu, manusia dalam hidup dan kehidupannya tidak pernah lepas dari simbol-simbol, setiap simbol itu ada maknanya tergantung dari individu atau kelompok mana yang memberikan pemaknaan dari simbol tersebut. Termasuk dalam praktek keagamaan.Misalnya Ibadah haji adalah ibadah yang penuh dengan simbol yang memiliki makna tersendiri, didalam pelaksanaannya.

Ibadah haji memiliki praktek-praktek ritual simbolik disebut dengan ihram, Thawaf mengelilingi Ka'bah, Sa'i, Wuquf di Arafah, Melontar jumrah, Hajar Aswad, Qurban dan Tahallul. Kesemuanya memiliki makna dalam pelaksanaannya: (a) Ihram; merupakan ritual dalam berhaji yang mewajibkan seorang haji memakai pakaian putih tanpa berjahit diartikan sebagai simbol pelepasan atribut keduniaan yang melekat pada manusia dan dianggap kembali fitrah seperti masa ia pertama kali dilahirkan. (b) Thawaf mengelilingi ka'bah; adalah salah satu rangkaian ibadah haji yang hanya bisa dilakukan di Baitullah yaitu mengelilingi ka'bah sebanyak tujuh kali putaran yang diawali dan diakhiri tepat pada garis Hajar Aswad, thawaf memberi pesan maknawi sebagai gerakan berputar pada poros bumi yang paling awal dan paling dasar. Tujuh kali putaran mengelilingi ka'bah, memiliki arti maknawi sebagai jumlah hari yang dijalani oleh umat manusia dalam setiap minggunya. (c) $S a$ 'i adalah rangkaian dari ibadah haji yaitu berlari-lari kecil sebanyak tujuh kali memberikan makna tentang dua hal yaitu tawakkal dan ikhtiar. (d) Wukuf di Arafah bermakna berhenti yaitu ritual haji yang mengajari umat Islam untuk sejenak meninggalkan aktivitasnya selama beberapa jam, yaitu berhenti dari kegiatan apapun agar bisa melakukan perenungan jati diri. (e) Melontar jumrohadalah salah satu wajib haji yang dilaksanakan oleh para jamaah haji. Tiga tugu yang terletak di Mina senantiasa dilempari dengan batu kerikil oleh jamaah haji, melempar jumroh adalah simbol perlawanan terhadap setan yang harus dilakukan terhadap setan karena mereka selalu berupaya menyesatkan dari jalan Allah SWT.(f) Hajar Aswad merupakan sebuah batu yang diyakini oleh umat Islam berasal dari surga dan yang pertama kali menemukannya adalah Nabi Ismail As. Mencium Hajar Aswad berarti membersihkan hati dari dosa-dosa. (g) Qurbanmerupakan rangkaian dari ibadah haji yang memerintahkan untuk menyembelih hewan yang berupa kambing, sapi atau kerbau untuk dibagikan kepada sesame. Ini menjadi cara untuk mendekatkan diri kepada Ilahi. (h) Tahallul;Tahallul secara leksikal diartikan dihalalkan, yaitu mencukur minimal tiga helai rambut merupakan simbol dari meletakkan mahkota seseorang, artinya orang tersebut menanggalkan kesombongan yang menjadikan seseorang tinggi hati terhadap orang lain (Husein, 2008). Semuanya itu merupakan rangkaian ritual ibadah haji yang penuh hikmah, makna dan simbol yang terinterpretasi kedalam suatu makna sesuai dengan motivasi para pelakunya. Ada tiga yang perlu diperhatikan, dianalisa sertai dimaknai oleh calon haji sebelum memutuskan untuk menunaikan ibadah haji yakni interpretasi, motivasi dan pengaruh (Putuhena, 2007).

Interpretasi calon haji terhadap ibadah haji sangatlah diperlukan untuk memahami motivasi mereka yang begitu kuat untuk melaksanakan ibadah yang begitu sulit dan memerlukan pengorbanan yang begitu besar. Interpretasi terhadap haji sebagai ibadah akan memunculkan motivasi untuk melaksanakan ibadah haji, sedangkan interpretasi terhadap kemampuan dan perjalanan haji akan berpengaruh terhadap penentuan pilihan 
terhadap waktu, cara perjalanan,dan pelaksanaan haji. Sedangkan motivasi yang dimaksud disini adalah suatu tendensi untuk bertindak menurut cara tertentu sesuai dengan kekuatan dari harapan bahwa tindakan itu akan diikuti oleh suatu konsekuensi yang diharapkan dan nilai dari konsekuensi itu bagi individu itu sendiri.Kemudian makna dari pengaruh adalah ada efek pemikiran dan terhadap tingkah laku secara pribadi dan masyarakat.

Penelitian sebelumnya yang memiliki relevansi dengan penelitian ini maka peneliti perlu mengungkapkan dua hasil penelitian yang berhubungan dengan penelitian ini. Sulthoni dkk., (2013) menyimpulkan bahwa pertama, haji pedagang memiliki pemaknaan yang relatif berbedabeda terhadap pelaksanaan ibadah haji yaitu (a) makna normatif (b) ibadah haji merupakan jaminan bagi terkabulkannya doa, (c) haji merupakan simbol atas status sosial dan kultural yang tinggi. Kedua, penciptaan aspek-aspek simbolik oleh para haji pedagang di pasar Beringharjo dilatar belakangi oleh kultural, sosial dan ekonomi. Ketiga, pelebaran, pergeseran dan perluasan makna haji dan penggunaan simbol-simbol haji sebagai manifestasi dari kesadaran kultural, sosial, dan ekonomi. Selanjutnya Penelitian ini dilakukan oleh Zukmawati (2018) mengungkapkan bahwa makna simbolik yang hadir dalam masyarakat Tonrorita bisa dikatakan lebih mengarah kepada penampilan fisik. Simbol yang melekat pada haji terletak pada apa yang ia kenakan sehabis pulang dari tanah suci. Cipo' dan Kopiah putih hanya digunakan sebagai alat untuk berinteraksi. Dari gambaran penelitian terdahulu, maka hubungan penelitian yang dilakukan dengan peneliti sebelumnya adalah sama-sama meneliti tentang simbol-simbol haji, namun dalam penelitian ini ada perbedaan dengan peneliti sebelumnya yaitu; peneliti bukan hanya fokus kepada makna dari simbolsimbol haji saja, tetapi peneliti ingin mendalami perilaku dan keistimewaan yang dimiliki oleh perempuan Bugis dalam pelaksanaan ibadah haji

\section{METODE PENELITIAN}

Jenis Penelitian ini adalah penelitian kepustakaan. Metode dokumentasi dilakukan untuk memperoleh data-data terkait penelitian. Setelah data diperoleh, teknik analisis data dilakukan menggunakan analisis konten. Kajian mengenai haji dan masyarakat bugis yang diperoleh dari metode dokumentasi dianalisis dan diuraikan

\section{HASIL DAN PEMBAHASAN}

Secara leksikal haji berasal dari kata hajja-al-hajju yang berarti ziarah, berkunjung atau pergi dengan maksud tertentu atau sengaja melakukan sesuatu tindakan atau perbuatan. Dalam hukum syariat memberikan pengertian bahwa haji sebagai tindakan untuk mengunjungi Makkah dengan tujuan untuk melakukan ibadah seperti thawaf, sai, melontar jumrah, wukuf di padang arafah, setiap pelaksanaan amalan tersebut sebenarnya memiliki makna mendalam yang harus diketahui oleh pelakunyasebagai bentuk kecintaan dan kepatuhan kepada Allah SWT guna untuk mendapatkan ridha-Nya (Sensa \& Artyasa, 2004). Istilah "haji" bukan hanya berada pada wilayah ibadah haji semata, ternyata didalam pelaksanaan ibadah haji ada juga pelaksanaan ibadah umrah yang tidak boleh ditinggalkan, sehingga dapat dikatakan tidak ada haji tanpa umrah. Para ulama membagi menjadi tiga model dalam pelaksanaan ibadah haji yakni, pertama; Haji tamattu'adalah model pelaksanaan ibadah haji dengan mengerjakan umrah terlebih dahulu pada bulan haji, kemudian mengerjakan ibadah haji pada tahun yang sama,tanpa terlebih dahulu kembali di daerah asal. Kedua; Haji Qiran yakni menggabungkan antara niat haji dan umrah dari batas dimulainya haji dengan mengucapkan talbiah "labbaika bi hajjin wa umrah.Ketiga; Haji Ifrad adalah model pelaksanaan ibadah haji dengan niat untuk ihram saja.Dimulai dari miqat kemudian membaca talbiah "labbaika bihajj". Model pelaksanaan ibadah haji ini harus berada dalam keadaan ihram sampai selesai melakukan amalan-amalan haji (Sensa \& Artyasa, 2004).

Haji adalah ibadah yang unik, kenapa dikatakan unik? Karena disatu sisi, secara syariat wajib hukumnya melaksanakan ibadah 
bagi setiap muslim yang baligh dan berakal sehat tetapi disisi lain tetap mengajukan pensyaratan yaitu istita'ah (mampu). Kemudian kemampuan disini diinterpretasikan secara luas dan mendalam oleh para ulama dan cendikiawan dari berbagai referensi dan buku-buku yang berhubungan dengan haji.Ada tiga syarat kemampuan yang harus terpenuhi dalam pelaksanaan ibadah haji yaitu mampu secara materi, fisik dan psikis. Tidak sedikit seorang muslim mampu secara materi dalam berhaji tapi kemampuan fisik tidak memungkinkan, maka mereka tidak boleh berhaji, ada juga seorang muslim mampu secara fisik dalam berhaji, tetapi kemampuan secara materi tidak ada maka dia tidak boleh berhaji. Ada juga seorang muslim mampu dari kedua-duanya yakni materi dan fisik tetapi psikisnya terganggu maka dia pun tidak boleh berhaji.

Jika haji dipandang sebagai ibadah yang menjunjung tinggi nilai-nilai kemanusiaan yang universal, maka pelakunya harus memulai dengan niat sambil menanggalkan pakaian biasa dengan mengganti pakaian ihram.Karena tidak bisa dipungkiri bahwa pakaian pada umumnya berfungsi sebagai pembeda antara seseorang dengan yang lainnya atau kelompok dengan kelompok lainnya. Pembedaan tersebut dapat mempengaruhi seseorang untuk membedakan dirinya dengan orang lain dari status sosialnya, profesi, ekonomi bahkan psikologis manusia itu sendiri.Makanya, pelaku haji harus menanggalkan semua pembedaan dan perbedaan itu, suku, ras, status sosial dan perbedaan lainnya.

Haji memiliki makna kemanusiaan yang universal, disaat mengenakan pakaian ihram, maka pelaku haji harus menghindari larangan-larangan dalam berhaji, menyakiti binatan, membunuh, mencabut pepohonan. Mengapa harus dilakukan? karena pada hakikatnya manusia diamanahkan oleh Allah untuk menjaga makhluk-makhluk Allah dengan memberinya kesempatan yang seluasluasnya untuk mencapai tujuan penciptaannya.

Masyarakat berarti sejumlah manusia dalam arti seluas-luasnya dan terikat oleh suatu kebudayaan yang mereka anggap sama.
Ralph Linton mengatakan "masyarakat adalah kelompok manusia yang telah hidup dan bekerja bersama cukup lama sehingga mereka dapat mengatur diri mereka dan menganggap diri mereka sebagai suatu kesatuan sosial dengan batas-batas yang dirumuskan dengan jelas".Konsep masyarakat dalam perspektif Selo Soemardjan diartikan sebaga orangorang yang hidup bersama dalam suatu wilayah yang membentuk kebudayaan (Soekanto, 2007). Dalam prosesnya, timbul suatu interaksi antar sesama yang menghasilkan ikatan dan mencerminkan perilaku. Salah etnis masyarakat di Sulawesi Selatan adalah masyarakat Bugis.

Suku Bugis adalah salah satu suku yang masuk kedalam golongan suku-suku Melayu Deutero yang menempati wilayah daratan Asia dikenal dengan nama Yunan. Dulu suku Bugis memiliki keyakinan bahwa mereka berasal titisan sang Dewata Sewwae dan turun ke bumi membawa aturan dan norma-norma sosial maka disebutlah dengan istilah to manurung. Asal-usul eksistensi suku Bugis sebagai awal kemunculannya, berasal dari kerajaan Cina terdapat di salah satu wilayah yang dinamai dengan pammana (Wajo). Kelompok masyarakat yang berada di wilayah kekuasaan La Sattumpugi maka mereka menamai dirinya To Ugi atau pengikut dari Raja La Sattumpugi. La Sattumpugi ini memiliki saudara yang bernama Batara Lattu, La Sattumpugi memiliki anak perempuan bernama We Cudai, sedangkan Batara Lattu memiliki anak bernama Sawerigading, kemudian We Cudai menikah dengan Sawerigading dengan pertalian darah (saudara sepupu). Melalui pernikahan tersebut, maka lahirlah salah seorang keturunan mereka yang bernama $\mathrm{La}$ Galigo yang memiliki karya sastra yang terpanjang dan terbesar di dunia.

We Cudai dan Sawerigading adalah dua tokoh berasal dari garis keturunan yang sama, maka hal ini menjadi salah satu ikon pada suku Bugis bahwa perempuan dan lakilaki memiliki kedudukan dan strata yang sama di masyarakat meskipun mereka memiliki peran dan fungsi yang berbeda. Suku Bugis dan termasuk juga suku-suku lainnya di Indonesia, lelaki dan perempuan 
memiliki aktivitas wilayah masing-masing. Namun pada hakekatnya orang Bugis tidak menganggap laki-laki maupun perempuan lebih dominan dalam menentukan setiap keputusan didalam rumah tangganya atau di tengah masyarakat. Hamzah menyatakan kriteria pembedaan peran gender itu lebih nampak kepada perilaku derajat dan status sosial di tengah masyarakat (Pelras, 2006). Oleh karena itu, masuknya Islam di Sulawesi Selatan khususnya di Tanah Bugis tidak serta merta dapat merubah alam pikiran dan kepercayaan mereka yang dianggap benar, apalagi Islam cuma dianggap bagian dari kebudayaan mereka pada waktu itu, dan kemudian ditambah dengan ideologi yang dibawa oleh penjajah dalam hal belanda yang berpengaruh kepada masyarakat bawah dan bahkan pengaruhnya sampai ke tingkat elit.

Berdasarkan pemikiran di atas, maka masyarakat Bugis masih membutuhkan proses dalam memobilisasi pola pemikiran, kepercayaan serta praktek-praktek sosial lainnya untuk menyesuaikan status dan peranannya sesuai dengan ajaran Islam yang mereka akui sebagai agamanya, termasuk dalam pelaksanaan ibadah haji. Ibadah haji merupakan bagian dari kepercayaan Islam yang bersumber pada Quran.Namun pelaksanaannya yang melibatkan komitmen dan pengalaman-pengalaman pelakunya (orang berhaji), ajaran wahyu yang murni itu mengalami pemekaran dan menjadi dinamis.Berbagai aspek sosial budaya yang mengitari para pelakunya turut menyertai realitas historis pelaksanaan haji. Di Indonesia, masalah perhajian berkaitan dengan aspek-aspek ideologi, sosial-budaya.

Khususnya masyarakat Bugis, minat masyarakat (umat Islam) menunaikan ibadah haji semakin meningkat ditandai dengan semakin meningkatnya masyarakat Islam Bugis yang istita'ah (mampu), baik mampu secara fisik maupun secara materi sebagai syarat dalam melakasanakan rukun Islam yang ke-lima itu, juga diasumsikan memiliki hubungan kausatif dengan dinamika kehidupan keagamaan, sosial, ekonomi dan budaya masyarakat. Bahwa meningkatnya jumlah jamaah haji setiap tahun dapat mengindikasikan kemantapan iman serta kesadaran keagamaan masyarakat yang memadai ditopang dengan persepsi dan pemahaman keagamaan yang relevan tentang haji.Selain itu, meningkatnya jumlah jamaah haji setiap tahun tingkat pendapatan masyarakat semakin memadai sehingga mereka dapat menemukan kemudahan memperoleh biaya atau ongkos naik haji. Hal lain turut mendukung meningkatnya gairah masyarakat naik haji ialah posisi dan peranperan sosial orang haji dalam konteks kehidupan sosial budaya masyarakat diharapkan akan diraih pula setelah menjadi orang haji.

Apabila haji dimaknai secara eksternal, maka memiliki tiga unsur sosial dalam pelaksanaannya: (1) mengandung unsur sosial yaitu adanya dorongan dari masyarakat agar mudah melaksanakan ibadah haji seperti melaksanakan manasik haji sebelum berangkat serta ritual-ritual lainnya. (2) Unsur politik yaitu adanya dukungan dari pemerintah yang berhubungan dengan persoalan administrasi yang berikan kepada orang yang berkompeten dibidang pemberangkatan haji. (3) unsur budaya yaitu terdapat dukungan moril yang bisa memperkuat identitas orang yang berhaji agar dapat memperoleh kedudukan yang tinggi dibanding masyarakat yang belum berhaji (Putuhena, 2007).

Haji sebagai tolak ukur dalam kehidupan sosial keagamaan masyarakat Bugis, simbol haji menjadi istilah yang dijadikan sebagai representasi dalam penggunaan simbol-simbol yang lainnya, melalui dengan perilaku dan cara berpakaian digunakan untuk merujuk kepada seluruh simbol-simbol kehajian, terutama dalam berperilaku dan berpakaian seorang haji pada masyarakat Bugis. Semua pakaian dari berbagai macam bentuknya adalah simbolik, semakin unik dan mahal pakaian seseorang maka semakin nampak pula identitasnya. Pakaian adalah salah satu cara melambangkan status sosial seseorang dalam masyarakatnya.pakaian dan gelar bagi seorang haji pada umumnya dianggap sebagai simbol yang berharga sehingga untuk menjabarkan digunakan teori interaksi simbolik yang mana membahas tentang 
kehadiran manusia diantara sesamanya tetapi sikap, nilai kepercayaan dalam kehidupan mereka.

Ada dua konsep yang mempengaruhi pemikiran orang Bugis terhadap persoalan ibadah haji yaitu konsep kesuksesan hidup dan konsep takdir. Konsep kesuksesan hidup; bagi orang Bugis, ibadah haji harus menjadi orientasi dan cita-cita luhur sebagai tujuan akhir dari kehidupan. Oleh karenanya, ukuran kesuksesan di dunia adalah menunaikan ibadah haji. Jika prinsip itu tertanam didalam jiwa seseorang, maka dia akan berusaha keras untuk memenuhi syarat-syarat pelaksanaan ibadah haji. Pada konsep takdir;bagi orang Bugis, meskipun banyak harta yang dimiliki oleh seseorang jika belum ada panggilan Allah untuk menunaikan ibadah haji, maka hal itu tidak akan terwujud makanya, kalau ada orang Bugis sudah mampu secara materi, kemudian ditanya "kenapa bapak/ibu belum berhaji padahal sudah mampu, maka mereka menjawab "deppigaga pangngolli'na puangnge" (belum ada panggilan dari Allah).

Bagi orang Bugis, simbol haji memiliki kekuatan untuk mengubah persepsi terhadap dirinya sebagai orang yang berhaji, dan juga merubah persepsi orang yang belum berhaji terhadap dirinya.Ia merasa berharga dan dihargai oleh lain di tengah masyarakat, sebagai orang yang berhaji, kesuksesan itu terlihat bukan hanya sukses dalam menyempurnakan rukun Islam tetapi juga sukses dalam memperoleh status sosial keagamaan di tengah masyarakat karena dianggap memiliki dana/pembiayaan dalam melaksanakan tugas dan tanggungjawab sebagai orang yang beragama Islam.

Pakaian juga ikut menentukan citra diri seseorang dalam berhaji.Dimana pakaian adalah cermin dari identitas, status, gender, memiliki nilai simbolik dan merupakan ekspresi cara hidup tertentu. Pakaian mampu memberikan gambaran dengan tepat bahwa saat kita memilih pakaian di rumah atau di tempat-tempat lain berarti kita mendiskripsikan diri sendiri.

Pakaian dan atribut kehajian adalah identitas haji yang paling menonjol keduanya merupakan berkah dari haji yang pertama sekali dan yang paling dihargai oleh orang
Bugis, karena haji pada waktu pulangnya, maka oleh orang lain hajinya dianggap tidak berberkah. Pada dasarnya pakaian haji ada dua yaitu pakaian yang dipakai sewaktu melaksanakan haji di Tanah Suci yang disebut pakaian ihram dan pakaian haji setelah menjadi haji.

Busana haji bagi orang Bugis terdiri atas busana yang dipakai pada acara-acara resmi dan busana yang dipakai seharihari.Busana untuk pakaian resmi inipun terbagi atas busana lengkap dan busana yang sederhana. Busana yang resmi adalah kabe, atau tippolo (sorban) bagi haji laki-laki, sedangkan busana resmi yang sederhana dipakai pada acara-acara adat (sorban) bagi haji laki-laki, sedangkan busana resmi yang sederhana dipakai pada acara-acara adat seperti perkawinan dan acara adat lainnya, terdiri dari taliling atau terispa' saja bagi haji perempuan dan songkok haji atau peci putih saja bagi haji laki-laki. Itulah busana yang membedakan antara seorang haji dan yang bukan haji, busana yang dipakai sehari-hari tidak jauh beda dengan busana yang sederhana ini hanya saja taliling atau terispa' diganti dengan cipo'-cipohaji yaitu sejenis topi khas perempuan yang dirancang khusus menyerupai taliling, tapi bukan taliling. Haji laki-laki simpel karena biasanya mereka hanya cukup dengan memakai peci putih.

\section{KESIMPULAN}

Status sosial merupakan perwujudan kemampuan diri dalam memahami pranatta di antaranya budaya-sosial, pendidikan, dan religi yang mendorong diferensiasi peran.Masyarakat mempunyai karakteristik unsur sosial seperti haji, dimana spirit perilaku keberagamaan menjadi penggerak terjadinya mobilitas sosial vertikal. Corak yang melekat pada simbol-simbol haji yang ditujukan kepada pelakunya menunjukkan interpretasi makna dari simbol-simbol haji yang melekat pada masyarakat Bugis. 


\section{DAFTAR PUSTAKA}

Blumer, H. (1966). Sociological Implication of the Thought of George Herbert Mead. American Journal of Sociology , 71, 535-544.

Husein, M. (2008). Hakikat Islam (Sebuah Pengantar Meraih Islam Kaffah). Yogyakarta: Pustaka Pelajar.

Pelras, C. (2006). Manusia Bugis. Terjemahan oleh Abdul Rahman Abu Dkk. Jakarta: Grafika Mardi Yuana Bogor.

Poloma, M. M. (2007). Sosiologi Kontemporer. Terjemahan oleh Tim Penerjemah Yasogama. Jakarta: Raja Grafindo Persada.

Putuhena, M. S. (2007). Historiografi Haji Indonesia. Yogyakarta: LKIS Yogyakarta.

Sarwono, S. W. (2012). Pengantar Psikologi Umum. Jakarta: Raja Grafindo Persada.

Sensa, M. D., \& Artyasa, U. S. (2004). Haji Spiritual (Makna Filofofis-Esoteris dalam Pendakian Ruhani. Bandung: Humaniora.

Soekanto, S. (2007). Sosiologi Suatu Pengantar. Jakarta: Raja Grafindo Persada.

Sulthoni, M., Muhlisin, \& Mutho'in. (2013). Haji dan Kegairahan Ekonomi: Menguak Makna Ibadah Haji bagi Pedagang Muslim di Yogyakarta. Jurnal Penelitian , 9(1), 49-65.

Zukmawati. (2018). Makna Simbolik Haji. Makassar: Universitas Negeri Makassar. 